\title{
Business Partner Roles of Management Accountants Through the Emergence of Sustainability Disclosures
}

\author{
Thinh Gia HOANG ${ }^{1}$, Trung Quang NGUYEN², Majo GEORGE ${ }^{3}$
}

Received: September 01, 2020 Revised: October 26, 2020 Accepted: November 05, 2020

\begin{abstract}
This study explores whether the implementation of sustainability disclosure can trigger or stimulate the change in the roles of management accountants in adopting organizations in Vietnam as business partners. To do so, it explores the roles of management accountants in integrated reporting (IR) adopting organizations and sustainability reporting (SR) adopting organizations based on the use of the pragmatic constructivism (PC) theoretical framework. In addition, qualitative semi-structured interviews were used to provide an in-depth investigation of management accountants' work in both IR and SR adopting organizations. The empirical findings suggest that the adoption of the IR framework has triggered changes in management accountant roles toward the new business partner roles to support the decision-making process within their organizations. On the other hand, management accountants from SR adopting organizations still work as traditional "bean-counter" roles. Our paper concludes by indicating several propositions based on our empirical findings that can be tested by future researchers from the domain by collecting relevant data. Our study can be seen as a response to the recent call for a more in-depth examination of the practice of sustainability disclosure from the practitioners' perspectives in adopting organizations.
\end{abstract}

Keywords: Management Accounting, Emerging Market, Sustainable Development

JEL Classification Code: M41, M14, Q01

\section{Introduction}

Organizational responsibility in reporting non-financial information has become a recent research agenda (De Villiers, Rinaldi \& Unerman, 2014; Tsai et al., 2020). Historically, most organizations generally assumed that their reporting duty was limited to disclosing only financial performance perspectives and information with the conventional view of focusing on short-term profit maximization. Nevertheless, the scenario has changed, and the social and environmental reporting or sustainability disclosure is emerging as policymakers, organizations, investors, and stakeholders realize that these issues eventually affect their overall long-term

${ }^{1}$ First Author and Corresponding Author, PhD Student, School of Business and Management, RMIT University, Vietnam [Postal Address: 702 Nguyen Van Linh, Tan Hung, District 7, Ho Chi Minh City, 700000, Vietnam] Email: s3788714@rmit.edu.vn

${ }^{2}$ School of Business and Management, RMIT University, Vietnam

${ }^{3}$ School of Business and Management, RMIT University, Vietnam

(c) Copyright: The Author(s)

This is an Open Access article distributed under the terms of the Creative Commons Attribution Non-Commercial License (https://creativecommons.org/licenses/by-nc/4.0/) which permits unrestricted non-commercial use, distribution, and reproduction in any medium, provided the original work is properly cited. sustainable development. A majority of accounting scholars (e.g. Terblanche \& De Villiers, 2019; Farooq \& De Villiers, 2019) highlight that non-financial information disclosure should be guided and prioritized as organizational strategy focuses on the future activities to preserve and generate values for shareholders and society.

According to De Villiers et al. (2014), sustainability non-financial reporting has a long developmental history. In the beginning, this kind of reporting took place mainly through reports within the financial disclosures of organizations. However, over the past 20 years, corporate social responsibility and environmental reports have been disclosed in separate independent reports, in addition to other corporate communication channels (Terblanche \& De Villiers, 2019). These sustainability reports have become longer and more complicated as a greater range of concerns have been reported to satisfy the expected information needs of a variety of stakeholders. As a result, various accountability systems for the disclosure of sustainability information has been introduced. Two reporting guidelines have emerged among these systems: the sustainability reporting (SR) guidelines and the integrated reporting (IR) framework (Harris et al., 2018; Hoang, 2018). 
Many essential consequences are attributed to these reporting guidelines, including fulfilling the information needs of stakeholders and driving organizational change towards more sustainable performance (Hoang, 2018; Hoang et al., 2020); reducing reputational risk, and allowing companies to make better decisions, as well as enhancing social and environmental performance (Burke \& Clark, 2016; Bernardi \& Stark, 2016; Hoang, 2018). This challenges management accountants as practitioners of these sustainability disclosure guidelines to claim or hold on to this space as the focus shifts towards this information in corporate reports (Harris et al., 2018). As a result, our study seeks to investigate the challenges and expectations that management accountants face during the development of SR and IR guidelines, and whether these reporting frameworks can challenge the traditional role of management accountants in the adopting organizations.

\section{Literature Review}

\subsection{Management Accountant Roles and Drivers for the Change in Management Accountant Roles}

A number of accounting scholars have described the modern role of management accountants as one of a business-oriented role (e.g. business partner role) or an internal advisor of the organization (Hopwood, 2008; De Loo et al., 2011). The business partner roles of management accountants proposed by Hopwood's (2008) type of the problem-solving accountant, highlighted the essentials of accounting information for decision making and the counterpart relationship between the management accountant and the other managers in their organization (Byrne \& Pierce, 2007; Fuadah et al., 2020). The development of this business partner role is based primarily on the advancement of management accountants to be more involved in daily operations and provide strategic accounting and business information for business operations (Baldvinsdottir et al., 2009). Besides, other accounting scholars such as Burns and (\&) Baldvinsdottir (2005) have claimed (for) the emergence of "hybrid accountants" as the assistants for strategic decision making within an organization. More recently, a variety of accounting scholars have advocated for the change in management accountant roles from one of the traditional "control" orientation to that of a "strategic" one which is named as "business partner" role. (e.g. Byrne \& Pierce, 2007; Hopwood, 2008; De Loo et al., 2011).

The role change of management accountants has attracted a lot of interest from accounting scholars (Järvenpää, 2007; Lambert \& Sponem, 2012). Accounting researchers have pointed out several factors that have stimulated the change of the management accountant's role. Communication has been highlighted as an essential perspective of management accountants' business partner role (Järvenpää, 2007). Byrne and Pierce (2007) noted that the cooperation and communication between management accountants and other managers improve social skills, interpersonal relations, and flexibility; hence, communication contributes to the leverage in the management accountant's role towards business partners (Byrne \& Pierce, 2007; Hopwood, 2008). Another factor that has been argued as a driver for the change in the management accountant role was the organization's regulations. Järvenpää (2007) suggests that the burden from regulatory initiatives has added more pressures of decisionmaking tasks for management accountants; for instance, De Loo et al., (2011) provides an example from the adoption of Sarbanes-Oxley law, which caused additional stress for management accountants regarding the management control inside the organization. Burns and Vaivio (2001) highlight change in the external business environment, another driver for a management accountant role change, and introduce a variety of examples for their argument, including the development of a new management control system or enterprise resource planning system within their organization. Caglio (2003) and Byrne and \& Pierce (2007) claimed for the advancement in technologies as drivers for management accountant change as it liberates management accountants from daily accounting information and focuses on assisting the decision-making process. Taken together, accounting scholars listed some drivers for the change of management accountant roles such as, internal communication in organization, the advancement in technologies, business environment, and accounting regulation.

\subsection{Sustainability Disclosure - Sustainability Reporting (SR) and Integrated Reporting (IR)}

The appearance of the concept of 'sustainable development' suggests a significant change in organization and stakeholder thought (Steurer et al., 2005; Steurer \& Konrad, 2009), driving businesses to consider their method of measuring organizational performance. At the organizational level, a sustainable development organization can be understood as one that meets stakeholders' requirements while applying a sustainable development strategy that provides them with financial benefits attained through environmental and social responsibility (Olivier, 2000; Sudana, 2015). From its introduction to the current period, most organizations respond to reports on sustainability performance to develop sustainability disclosure, either in combination with or separately from the organization's annual report (Bennett et al., 2017; Pham et al., 2020). There are two forms of sustainability disclosure reports currently used by organizations around the world; the first is the standalone sustainability reporting (SR) guideline, the other is the newly developed integrated reporting (IR) framework. There are a few differences in both sustainability disclosures; the 
SR communicates environmental, social, and governance performance and a summary of an organization's progress towards them. A SR is not often integrated with conventional financial annual reports and therefore criticized as tending to focus on the positives for attracting and satisfying current and potential shareholders.

More recently, several standard setters and regulatory bodies have worked together and introduced a new corporate reporting standard, named the (IR) framework. This was done to provide a holistic and concise story within the corporate performance of an organization, given its social, environmental, and economic operations and their impact to society and environment. The IR framework suggests that the financial and sustainability information should not be presented separately. In fact this information should be combined in a single statement that reflects an integrated method of handling various indicators and information to generate sustainable values (Barter, 2016). These capitals include financial, manufactured, intellectual, natural, social/ relationship and human capital. By concentrating on the interconnections between these capitals, an organization can present a bigger picture, highlighting the fundamental valuecreation process for readers (Adams et al., 2016).

Several scholars have studied the relationship between sustainability disclosureguidelinesandadopting organizations and suggest that voluntary sustainability disclosure can be seen as a change in business circumstance and additional regulation. This has also triggered internal communication and facilitated the development of new management systems in adopting organizations (Adams et al., 2016; McNally et al., 2017). Given these factors leading to the changing role of the management accountant, drawn from the management accountant literature review (e.g. communication, technology, business environment, regulation) and the impact of the IR framework to its adopting organizations (e.g. change in business circumstance, communication improvement and the development of new management system) (Barter, 2016), it is reasonable to raise a question - whether the development of sustainability disclosure such as SR and IR can hold the potential to stimulate change in management accountant roles as the practitioners of these reporting guidelines in adopting organizations.

\section{Pragmatic Constructivism Theoretical Framework}

The scarcity of fully developed domain theories in management accounting literature to explain, analyze, and reflect management accountant practices have been claimed by several researchers (Norreklit et al., 2010; Lukka and Vinnari, 2014). Given the centrality of the management accountants' practice, pragmatic constructivism (PC) is adopted as a method theory (Lukka and Vinnari, 2014), which offers a structural basis to collect and analyze data for this study. PC focuses on how management accountants work and contribute to the reality of the organization that they are working in, in meaningful action (e.g. the implementation of sustainability disclosure guidelines). PC can provide a theoretical framework for assessing management accountant practices because it reveals how the practice happens concerning its real organization context (Norreklit et al., 2010; Huyen Do et al., 2020). PC includes four dimensions facts, possibilities/ logic, values, and communication.

Management accountants provide the facts that reflect the substance of the accounting profession. There are several types of facts relating to accounting. The first one is that which stands for the physical presence of goods or services such as inventories (Norreklit et al., 2010). The second factual type is the one that is constructed, for example, costs and profits. Both of them are needed to be recognized in the broader society, therefore becoming institutionalized. The third factual type pertains to future estimates such as budget forecasts and residual values of an asset. People may identify and favor different possibilities, even from the same set of recognized facts. Thus, possibilities can amplify the complexities and differences of facts. In a management accounting context, logic/ possibilities can build cumulatively on facts, and relate to the information production practices of management accounting and the interpretation of information.

There is a distinct possibility of management accounting practice gaining over time due to the advancement of new approaches that are evolved and employed. This is due to improvement in technology, their practical approaches, and the increase in regulations regarding the context of management accountants practices. Values are the inspiring forces of a person (Norreklit et al., 2016; Phornlaphatrachakorn \& Khajit, 2020). Their work is known for finding facts and analyzing possibilities. Besides, they give you a reason for choosing a possibility that is of greater value than the others. Values help to transfer the will and efforts of the individual into action. In management accountant practice, communication stays at the center of practice. Accountants have to communicate with the data provided to them to the users of the information that they produce. The criticality of communication is inherent in the management accountant supporting roles, which has been so heavily promoted in recent management accounting literature. Communication is a vital component of management accounting practice. It can take many forms of management accountants in the organizational context such as face-to-face discussions, group or individual presentations, hard copy or computer access, detailed or summarized, raw information, or analyzed and interpreted information. Communication can offer an important source for the change and the difference in management accounting practices (Norreklit et al., 2010). The four dimensions for assessing management accountant practices motivated by the PC (theoretical lens is indicated in figure 1. 


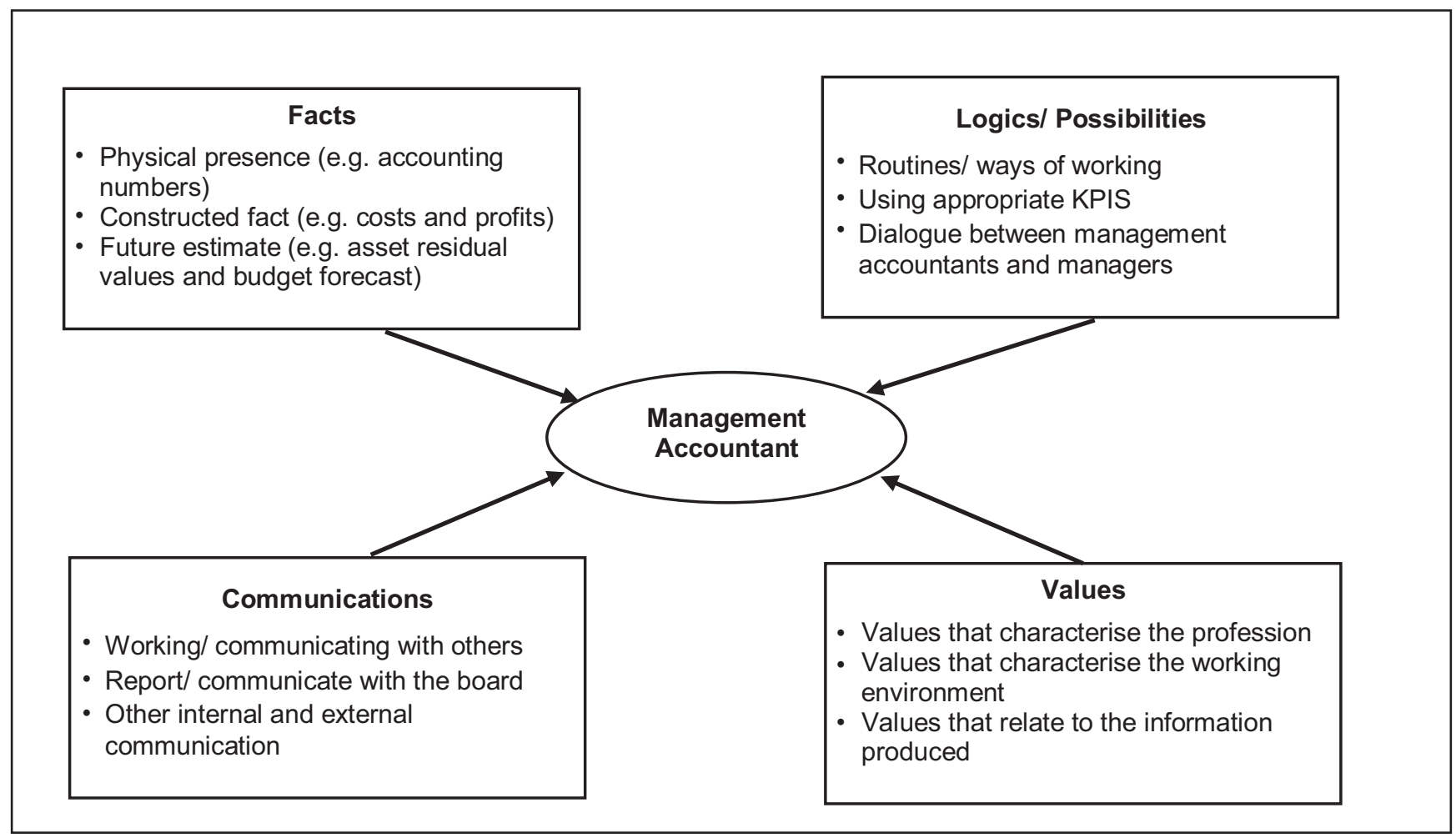

Figure 1: Theoretical Framework of changes in Management Accountant roles (source: author)

\section{Methodology}

This research adopts the qualitative interpretive method in order to respond to the recent call for further exploratory research to the management practices of SR adopting and IR adopting organizations (Nguyen et al., 2019). Regarding the sample collection, to identify sustainability disclosure adopting organizations, authors went through the list of IR implementing organizations provided by the International Integrated Reporting Committee (IIRC) (access via https://integratedreporting.org/ and http:// examples.integratedreporting.org/), then we manually searched on their subsidiary website in Vietnam to identify the list of organizations which released an integrated report in Vietnam. Further, the list of SR-adopting organizations will be selected randomly from two Vietnamese stock exchanges, Hanoi stock exchange (https://www.hnx.vn/) and Ho Chi Minh City stock exchange (https://www.hsx.vn/). In order to maintain generalizability of this study, research samples include organizations from a variety of sectors (e.g. FMCG, oil and gas, financial service, etc.). Investigators approached key people committed to preparing corporate reports inside the participating organizations. The interviews were conducted in both IR and SR adopting organizations with management accountants and other managers, who were voluntary participants. In addition, relevant published documents on the websites of these participating organizations were collected for further analysis. Regarding sample size, we interviewed 18 management accountants at different levels and positions from IR adopting organizations and six management accountants from SR adopting organizations. Each interview with participant took about one hour to one hour 30 minutes. Details of the interviews are presented in Table 1 and Table 2.

Regarding data analysis, the PC framework is also employed again as a data analysis methodology to facilitate the comparison of management accounting practices and management accounting roles in both IR adopting and SR adopting organizations. Semi-structure interviews have been used to gain an in-depth understanding of the research participant's perspective and experience (Nguyen et al., 2019). After all of the interviews were recorded and transcribed, all interview data were entered, analyzed, and coded in QSR Nvivo software to recognize the specific issues from the data collection stage. Common insights and themes from all interviews were developed, and direct quotations from interviewees are presented to prove the investigation's credibility. 
Table 1: Participants from sustainability report adopting organizations

\begin{tabular}{|l|l|c|c|c|}
\hline No. & Job title of interviewees & Sector/industry & Organization code & Working experience (years) \\
\hline 1 & Financial Manager & Construction & S1 & 19 \\
\hline 2 & Financial Controller & Dairy & S2 & 12 \\
\hline 3 & Financial Manager & Financial services & S3 & 22 \\
\hline 4 & Management Accountant & Bank & S4 & 10 \\
\hline 5 & Financial Manager & Agriculture & S5 & 12 \\
\hline 6 & Financial Controller & Oil and gas & S6 & 15 \\
\hline
\end{tabular}

Table 2: Participants from integrated report adopting organizations

\begin{tabular}{|l|l|l|c|c|}
\hline No. & \multicolumn{1}{|c|}{ Job title of interviewees } & Sector/ industry & Organization code & Working experience (years) \\
\hline 1 & Management Accountant & FMCG & 11 & 15 \\
\hline 2 & Financial Manager & FMCG & 11 & 17 \\
\hline 3 & Business Intelligence Manager & FMCG & 11 & 20 \\
\hline 4 & Financial Controller & FMCG & 12 & 13 \\
\hline 5 & General Manager & FMCG & 12 & 15 \\
\hline 6 & Financial Manager & Beverages & 13 & 20 \\
\hline 7 & Business Solutions Manager & Beverages & 13 & 10 \\
\hline 8 & Management Accountant & Beverages & 13 & 17 \\
\hline 9 & Financial Controller & Bank & 14 & 13 \\
\hline 10 & Financial Manager & Bank & 14 & 13 \\
\hline 11 & Head of Communications \& Banking & Bank & 14 & 20 \\
\hline 12 & Business Development Manager & Oil \& Gas & 15 & 27 \\
\hline 13 & Financial Manager & Oil \& Gas & 15 & 25 \\
\hline 14 & Financial Manager & FMCG & 16 & 23 \\
\hline 15 & Deputy General Manager & FMCG & 16 & 22 \\
\hline 16 & Chief Accountant & Insurance & 17 & 17 \\
\hline 17 & Deputy Director & Insurance & 18 & 13 \\
\hline 18 & Financial Manager & Oil \& Gas & & \\
\hline
\end{tabular}

\section{Data and Analysis}

The findings are structured in a manner that follows the PC framework regarding the influences of sustainability disclosure guideline implementation on management accountants' roles. These are supported throughout using verbatim quotes capturing the interviewees' perspectives on four dimensions of PC theoretical lens regarding the sustainability disclosure practices to management accountant role as the primary practitioners of sustainability disclosure through IR and SR adoption in their organizations.

\subsection{Facts}

The "facts" dimensions relate to information associated with the foundation of management accountants' work. It may include accounting information or indicators that management accountants have worked with, the guidelines or accounting framework that they need to refer as well as tasks and responsibilities that define their roles. Several accounting scholars such as Burns and Baldvinsdottir (2005) and Phornlaphatrachakorn and Peemanee (2020) highlighted the influence of additional accounting regulations as the 
main drivers for changing roles of management accountant toward business partner roles. Sustainability disclosures in both SR and IR can also be understood as the additional sustainability regulation that directly impacts the work and the responsibilities of management accountants as the main practitioners. While participants from IR adopting organizations saw the change in management accountants roles toward business partners, interviewees from SR adopting organizations claim that management accountants "play a very little role" (Financial controller, S2) in the development and preparation of sustainability disclosure.

In addition, although management accountants from both SR and IR adopting organizations report the appearance and the importance of sustainability information in corporate reports, participants from SR adopting organizations considered the work with such data as a great challenge for management accountants:

"I think the non-financial information is the important aspects of management accountant role in comparing with other accountants in a company; however, the fundamental challenge for us is that we unable to measure the nonfinancial things. For example, we usually measure operating expenditure based on our experience rather than relying on the business or accounting information system" (Financial Controller, S2)

On the other hand, management accountants from IR adopting organizations contribute significantly to the development of integrated reports as well as sustainability disclosures. Depending on different IR adopting firms, management accountants contribute differently to the development of the integrated report. Two organizations, I7 and I8, aimed to create an integrated report with the help of the consultant from a professional accounting and financial service firm. Management accountants from I7 and I8 worked with consultants to develop an integrated report, including sustainability information.

In two other organizations, I1 and I2, management accountants got involved and helped to develop new KPIs regarding the adoption of the IR framework. The General Manager - Business Intelligence at I1 claims that "it had become increasingly difficult" at the initial stage of IR adoption, as their report must satisfy different external stakeholders who required different information from the corporate reports. To deal with this issue, I2 mentioned "the integration work between financial and non-financial staffs" (General Manager - Sustainability Business, I2). Specific KPIs were developed by collaborative work between management accountants and other managers (General Manager-Sustainability Business, I2). Meanwhile, I1 referred to "the guidelines" and "other competitor's reports" as being influential in determining their KPIs (Financial Manager, I1).
To develop sustainability-related KPIs in I4, I6, I5, and I3, the cross-functional group, which included the participation of management accountants and other managers to develop the integrated report, identified a list of indicators that followed the IR framework such as the human, the social and environmental capitals. The IR development group met regularly to discuss and review the appropriate progress for the integrated report. The Financial Manager at I4 describes the development of sustainability KPIs in I4 and the benefits that their KPIs contributed to highlighting value creation in I4:

“... requirements in the IR framework implies the practices and development by all people in our company to enhance workflow and advancement in each business functions ... business operation is measured by new particular indicators, resulted from the work of management accountants and other people in our firm..." (Financial Manager - I4).

In addition, a number of sustainability-related KPIs had never been implemented before; the development of these indicators required collaboration between management accountants and managers during the preparation of the integrated report:

"Each function in our company has a number of indicators and a set of measurement related to it, allows us to bring out an integrated view of performance... These tasks also require the engagement of management accountants and managers from all parts of the organization working together to deliver a common achievement..." (Financial Manager - I6)

In summary, a contrasting result has been found from the two groups of SR adopting organizations and IR adopting organizations. Management accountants from IR adopting firms have contributed to the sustainability initiatives in their organizations; however, a similar result has not been found from management accountants at SR adopting organizations. Table 3 provides a summary of findings from this section.

\subsection{Possibility/Logic}

While the facts provide the foundation for action, actions further depend on the logic or possibilities for the action in reality. Therefore, actors, in reality, need to identify possibilities before taking actions. In the management accounting context, logic/ possibilities can construct cumulatively on facts, and it relates to the information production practices of management accounting and the information interpretation. The "possibility/ logic" implies the manner in which the management accountant engages in the preparation of sustainability disclosure in a sustainability report and integrated report. 
Interviewees from SR adopting organizations were asked who was responsible for the development of sustainability reports. Also whether a management accountant could play any role in the preparation of these reports? Interviewees replied, that the management accountant plays a very small role in the SR development process. On the other hand the Investor Relations Team or Communication Departments are the primary preparers of corporate reports. Management accountants also engage a little bit in the preparation of sustainability reports. However, their engagement relates more to helping the preparer to understand the reporting of financial performance rather than genuinely contribute to sustainability issues.

"I am engaged in the team that undertake strategic decision, plans, across our organization. However, my main roles more relate to support people from the communication team about numbers or accounting information in our enterprise resources planning system rather than prepare any report" (Financial Manager, S5)

Participants from IR adopting organizations mentioned a variety of ways in which to develop integrated reporting with sustainability disclosure in their organizations. The author observed three different adoption approaches in eight IR adopting organizations. In the first four cases (I3, I4, I5, I6), which adopt the "push" strategy (Stubbs \& Higgins, 2014), these organizations which adopt the IR framework to drive the change of sustainability in their organizations, involve cross-functional groups as a part of this organizational dialogue. Managers from these organizations expected that this "push" approach be "able to drive the sustainability" (Financial Manager - I3) for the business.

"I can see a huge benefit for doing this; sustainability is driven and promoted by the sustainability disclosure. It's a good way to go about promoting change of and develop organizational strategy. Normally, the corporate report should include the output of organizational strategy and business performance. However, we now trying to use the report to encourage the other way. I believe it potentially works as it encourages communication between everyone, and communication can help to solve any problems" (Financial Manager - I6).

Two organizations I1 and I2 followed the "pull approach"; they affirm that their integrated report was a result of "an integrated sustainability business system" (Management Accountant - I1). Interviewees spoke about their integrated report as "a part of our organizational management system" (General Manager - Sustainability Business- I2) and "vital to how we manage this corporation" (Financial Manager I1). Also, interviewees of I1 and I2 described the integrated business system as a system that is accountable for social and environmental externalities besides reporting the value creation process and embedding sustainability practices to the organization. The General Manager - Business Intelligence at I1 also provided additional information about his experience of I1's IR implementation process:

"My job is rather to integrate sustainability into our core value creation process. I worked for more than 5 years in this system without a thought of sustainability matter. Then our leaders decided adopt the sustainable development strategy followed by integrated report, a communication that we think to match our development purpose" (General Manager - Business Intelligence, I1).

In the last two organizations (I8, I7) their integrated report is generated by the assistant of their external consultant - a professional accounting and financial service firm, rather than implement it from the inside of the organization. The main tasks of the management accountant are to "provide the supporting data and related documentation and reports" (Deputy Director, I7) to their consultants. The Chief Accountant reports his thought about using IR development at I7:

"...Since the beginning to now, I still not know much about the IR framework. The accounting team simply looking and working followed requirements from our consultants. Then they worked on our information and develop the report for our company..." (Chief Accountant - I7)

\subsection{Values}

Regarding the context of management accountants' practices, values are the inspiring forces of a person. They work for finding facts and analyzing possibilities. Besides, they bring the reason for choosing between alternative possibilities in order to determine the possibility of one that is more valuable than others. In addition, values help to transfer the will and efforts of the individual into action. All professionals should work based on developed values that will provide their professional credibility. Regarding the management accountant role, values either represent the organization that employs them or the technical values related to the information produced by management accountants.

Current research reports that the role of the management accountant change might arise from closer communication between organization managers, leaders, and management accountants. (Järvenpää 2007; Baldvinsdottir et al., 2009) suggest that working closely between the management accountant and manager can stimulate the management accountant to be more involved in the strategic development of their organizations. Given the fact that sustainability 
disclosure is a strategic plan by adopting organizations, findings from SR adopting organizations show that management accountants still work in isolation and did not engage much in sustainable initiatives of these organizations as confirmed by a financial controller:

“. . . in the future, maybe we will get involved in supporting the board with our understanding of financial and non-financial experience such as the measurement of human resources of intellectual asset valuation. However, currently, we do some accounting tasks such as budgeting or cost-benefit analysis" (Financial Controller, PDV)

In IR adopting organizations, the work of the management accountant regarding sustainability disclosure and integrated reporting preparation has been linked to their organizations' management control system. In three organizations, FCMG2, $\mathrm{I} 5$, and I4, the balanced scorecard (BSC) is employed as a performance tool used in management to improve a business's internal functions and external outcomes. The development of SR and the later IR is conducted based on the balanced scorecard which are very useful

"Balance scorecard is adopted as essential part in our organization [. . .] Although the board decided to implement IR framework, however, we were in the habit of taking important managers and business operation under control with the balance scorecard, and when we decide to move to sustainable development, the adoption of balance scorecard still prove it useful to link the conventional economic aspect with the sustainability aspect" (Financial Manager, I4).

Although I8 and I7 have formally adopted IR, they still rely upon the "traditional state-owned management control system" as their informal mechanism to align the internal control system, and they argued that it still proved a useful mechanism for management. However, recently, the reform in the Vietnam economy, as a result these firms are expected to become more market- and profit-oriented, is now placing considerable pressures upon these companies and forcing them to change. One interviewee explained the change in "traditional state-owned management control system":

“... 5 years ago, this organization was a small firm. I mean, everyone knows each other. So, our corporate culture is very well understood. . from management right down to all business divisions and staffs. Five years later, we have an organization that's three-times bigger with branches across many big cities of Vietnam; you've got a very different organization... however the corporate culture still being used as we are in the transformation stage and can't try new management system." (Chief Accountant, I7)
In I1, I2, and I3, the participants affirmed that the integrated report's KPIs did not exist in isolation but were integrated with the whole sustainable business system. One of the performance objectives of accounting people, for instance, was to develop KPIs for corporate social responsibility in the local business context. Table 5 provides a summary of findings from this section.

\subsection{Communication}

In management accountant practice, communication stays at the center of practice. Accountants have to communicate, with data provided to them, and with the users of the information that they produce. The criticality of communication is inherent in the management accountant supporting roles, which has been so heavily supported in the recent management accounting literature. Furthermore, communication is not merely an input preceding action, but also an action output in its own right, as is reported, presentations such as the context of sustainability disclosure that fit this study's context.

Remarking on communication between management accountants and the managers and preparers surrounding the development of corporate reports; a standard view amongst interviewees was that there is a lack of interaction between management accountants and other people in their organization except for special circumstances such as the preparation of financial parts of corporate reports. The Financial Manager of S5 also showed mixed feelings about the communication; the following quote illustrates tensions between accountants and the preparers of organizational reports:

“...the relationships between preparers and my people [management accountants] was not significant, but I think it was helpful. We did help them to get the data flowing in a far more effective way than they had been done it alone in the past, which was information coming from all parts of our organization..."

On the other hand, communication and interactions of management accountants from IR adopting organizations have changed significantly due to their participation in different dedicated groups to develop integrated reports. In most IR adopting organizations, a dedicated group is mentioned as a crucial mechanism for the successful IR adoption in organizations that intend to use IR as a tool to drive organizational change toward sustainability. These groups used by IR adopting organizations can be perceived as integrated thinking in practice. Consistent with the IR framework, these IR adopting organizations involved all people from different departments in their sustainability disclosure development processes 
“... we had the blended group which includes together a lot of people from financial, marketing, communication, risk functions to have that conversation. So, it's a larger conversation, and it implies a lot of what our business's doing daily, about management control and about materiality, rather than reach sustainability purpose". (Management Accountant - I3)

\section{Discussion}

This section provides a discussion of the main findings. Propositions developed as a result of this are listed subsequently. A significant difference between IR adopting organizations and the SR adopting ones, is the responsibility and role of management accountants in the development of integrated and sustainability reports. In SR adopting organizations, the corporate reports (including both the annual report and the sustainability report) are developed and prepared by people in the communication, investor relations, or sustainability groups. There is no involvement of management accountants in developing and preparing sustainability disclosure. Nonetheless, in all seven IR adopting organizations, there appeared to be a lot of engagement of the management accountants and other managers within IR development. McNally et al., (2017) found that although business leaders supported the sustainable development idea, the management accountants did not work with or own the sustainability report (they were "isolated" from the sustainability staff).

In addition, Stubbs and Higgins (2014) found that although IR is moving beyond the sustainability group, sustainability is still confined, and the IR discourse is not penetrating financial areas. What is surprising is, in all IR adopting organizations, the ownership of IR is a mechanism to manage the shift from annual and sustainability reporting to the integrated one. In the IR internal adopting organizations, that were analyzed, the author found that, in the beginning, the accounting team did not initiate or own corporate accounting. Nonetheless, the implementation of IR framework moved beyond the communication and sustainability discourses over time. Two organizations moved its IR to the finance managers, whereas management accountants in three other IR adopting organizations have engaged in preparing, developing, or collecting IR data. In two IR external adopting organizations, although external consultants developed IR, they still worked closely with the board and management accountants (Stubbs \& Higgins, 2014). A possible explanation for these results may be that the IR framework is the concise corporate reporting guideline that combines both financial and sustainability disclosure into a single report. In contrast, the sustainability report is a standalone report. Therefore, management accountants are unable to engage only in the sustainability part of the sustainability report. Hence, a number of propositions can be drawn:

Proposition 1: The adoption of sustainability reporting guidelines alone are unable to lead to change in the management accountant's role due to the lack of connection between the sustainability part and the financial part.

Proposition 2: The implementation of an integrated reporting framework can trigger the change in the management accountant's role due to the integration of financial and sustainability aspects.

Another critical difference in IR adopting organizations that cannot be found in the SR adopting organizations is the increase in management accountants' communication. On the one hand, interviewees from SR adopting organizations reported that accountants are only involved in matters associated with the use of financial information (Hoang et al., 2020). Besides, management accountants work is insulated in financial positions, and there is not much effort to crossreference, communicate, or try to tie the two financial and non-financial parts in their organizations (Hoang et al., 2020). On the other hand, management accountants in IR internal adopting organizations have participated in crossfunctional groups. These IR development teams include engagement from both senior managers and management accountants who actively commit to IR development (Hoang, 2018). The establishment of these teams creates closer links between certain types of non-financial information, financial information, and organizational strategy and requires more communication between management accountants and other parts of their organization to develop appropriate KPIs to meet sustainability disclosure. As a resulted, two more propositions can be concluded:

Proposition 3: The mere adoption of sustainability reporting guidelines is unable to increase the communication of the management accountant with other parts of the organization.

Proposition 4: Implementing an integrated reporting framework can trigger a management accountant's internal communication with other managers inside the organization.

\section{Summary and Contributions}

Our study can be seen as a response to the recent call for a more in-depth examination of the practice of sustainability disclosure from practitioners' perspectives. The purpose of this study was to explicitly explore whether sustainability disclosure can trigger the change in the work and roles of management accountants as the main practitioners 
of this initiative. We compare the roles of management accountants from two groups of IR adopting organizations and SR adopting organizations. Interestingly, management accountants' different responsibilities and roles have been found from two groups of IR adopting organizations and SR adopting organizations. Our paper concludes by indicating many propositions based on our findings that can be tested by future researchers from the domain by collecting relevant data.

In terms of a practical contribution, the study attempts to shed light on the intricate nature of the current work and management accountant practices regarding the sustainability disclosure in both IR adopting organizations and SR adopting organizations in Vietnam. Our study suggests that the integration of financial and sustainability aspects in the IR framework has triggered a change in management accountants' roles in the context of Vietnam. Regarding the theoretical contribution, the researcher adopts the PC as it offers a structural way to collect and analyze data for this study. It is the most suitable theoretical platform to explore the management accountants' work and roles in both IR adopting and SR adopting organizations. First, the integration of four PC dimensions provides a means of exploring and explaining how management accountants in different roles relate to the reality in which they exist. Also, the PC paradigm highlights the role of communication in the differences of perception between management accountants and their relations. The PC structure enables the researcher to delve down to explore the complex interrelationships between management accountants and their working environment, facilitating comparisons between their roles in different contexts. Second, the existing gap between management accounting research and practice has been raised and discussed by many accounting scholars. This research adopts the PC theory as the main research paradigm for this study to bridge this gap. It provides a rich descriptive analysis of how management accountants practice in different contexts. This facilitates the understanding of research needs and demonstrates the usefulness of this research for practice.

Our study is subject to some limitations, which can pave the way for future research. We recognize that the sample of participants and organizations in this research, while considered leading organizations in sustainable disclosure guideline adoption, is limited by focusing on a single country. Therefore it is recommended that, additional studies should compare the roles of management accountants from different countries. Furthermore, future research is needed to consider the organizational context, technology, leadership, and other supporting roles of the management accountant to understand management accountant practices regarding sustainability disclosure implementation.

\section{References}

Adams, C. A., Potter, B., Singh, P. J., \& York, J. (2016). Exploring the implications of integrated reporting for social investment (disclosures). British Accounting Review, 48(3), 283-296. https://doi.org/10.1016/j.bar.2016.05.002

Baldvinsdottir, G., Burns, J., Nørreklit, H., \& Scapens, R. W. (2009). The image of accountants: From bean counters to extreme accountants. Accounting, Auditing and Accountability Journal, 22(6), 858-882. https://doi.org/10.1108/09513570910980445

Barter, N. (2016). A review of "A New Vision of Value" - old wine, new bottle. Sustainability Accounting, Management and Policy Journal, 7(4), 531-538. https://doi.org/10.1108/ SAMPJ-12-2015-0111

Bennett, M., James, P., \& Klinkers, L. (2017). Sustainable measures: Evaluation and reporting of environmental and social performance, Abingdon, UK: Routledge.

Bernardi, C., \& Stark, A. W. (2018). Environmental, social and governance disclosure, integrated reporting, and the accuracy of analyst forecasts. British Accounting Review, 50(1), 16-31. https://doi.org/10.1016/j.bar.2016.10.001

Burke, J. J., \& Clark, C. E. (2016). The business case for integrated reporting: Insights from leading practitioners, regulators, and academics. Business Horizons, 59(3), 273-283. https://doi. org/10.1016/j.bushor.2016.01.001

Burns, J., \& Baldvinsdottir, G. (2005). An institutional perspective of accountants' new roles-the interplay of contradictions and praxis. European Accounting Review, 14(4), 725-757. https:// doi.org/10.1080/09638180500194171

Burns, J., \& Vaivio, J. (2001). Management accounting change. Management Accounting Research, 12(4), 389-402. https:// doi.org/10.1006/mare.2001.0178

Byrne, S., \& Pierce, B. (2007). Towards a more comprehensive understanding of the roles of management accountants. European Accounting Review, 16(3), 469-498. https://doi. org/10.1080/09638180701507114

Caglio, A. (2003). Enterprise Resource Planning systems and accountants: towards hybridization? European Accounting Review, 12(1), 123-153. https://doi. org/10.1080/0963818031000087853

DeLoo, I., Verstegen, B., \& Swagerman, D. (2011). Understanding the roles of management accountants. European Business Review, 23(3), 287-313. https://doi.org/10.1108/09555341111130263

De Villiers, C., Unerman, J., \& Rinaldi, L. (2014). Integrated Reporting: Insights, gaps and an agenda for future research. Accounting, Auditing \& Accountability Journal, 27(7), 10421067. https://doi.org/10.1108/AAAJ-06-2014-1736

Farooq, M. B., \& De Villiers, C. (2019). Understanding how managers institutionalize sustainability reporting. Accounting, Auditing \& Accountability Journal, 32(5), 1240-1269. https:// doi.org/10.1108/AAAJ-06-2017-2958 
Fuadah, L. L., Safitri, R. H., Yuliani, Y., \& Arisman, A. (2020). Determinant Factors' Impact on Managerial Performance through Management Accounting Systems in Indonesia. Journal of Asian Finance, Economics and Business, 7(10), 109-117. https://doi.org//jafeb.2020.vol7.no10.109

Harris, E., Hoang, T. \& Ngan, G. (2018). Accounting for capital investment appraisal: time for a radical change? In: M. Quinn \& E. Strauss (Eds.), The Routledge Companion to Accounting Information Systems (pp. 173-189), Abingdon, UK: Routledge. http://dx.doi.org/10.4324/9781315647210-14

Hoang, T (2018). The role of the Integrated Reporting in raising awareness of environmental, social, and corporate governance performance. In: D. Crowther \& S. Seifi (Eds.), Stakeholders: Governance and Responsibility (pp. 47-69). London, UK: Emerald Publishing Limited. https://doi.org/10.1108/S2043052320180000014003

Hoang, T. G., Vu, T. K., Nguyen, H. T., \& Luu, H. N. (2020). Mandatory Integrated Reporting Disclosure and Corporate Misreporting. Journal of Applied Accounting Research, 21(3), 363-382. https://doi.org/10.1108/JAAR-02-2019-0025

Hopwood, A. G. (2008). Management Accounting Research in a Changing World. Journal of Management Accounting Research, 20, 3-13. https://doi.org/10.2308/jmar.2008.20.1.3

Huyen Do, T., Le, H. M., Luong, D. T. T., \& Tran, Q. T. (2020). Relationship between the Management Accounting Information Usage, Market Orientation and Performance: Evidence from Vietnamese Tourism Firms. Journal of Asian Finance, Economics and Business, 7(10), 707-716. https://doi.org// jafeb.2020.vol7.no10.707

Järvenpää, M. (2007). Making Business Partners: A Case Study on how Management Accounting Culture was Changed. European Accounting Review, 16(1), 99-142. https://doi. org/10.1080/09638180701265903

Lukka, K., \& Vinnari, E. (2014), Domain theory and method theory in management accounting research. Accounting, Auditing \& Accountability Journal, 27(8), 1308-1338. https://doi. org/10.1108/AAAJ-03-2013-1265

McNally, M. A., Cerbone, D., \& Maroun, W. (2017). Exploring the challenges of preparing an integrated report. Meditari Accountancy Research, 25(4), 481-504. https://doi.org/10.1108/ MEDAR-10-2016-0085

Nguyen, H; Hoang, T. G; \& Luu, H. (2019). Corporate Social Responsibility in Vietnam: Opportunities and Innovation Experienced by Multinational Corporation Subsidiaries. Social Responsibility Journal, 16(6), 771-792. https://doi.org/10.1108/ SRJ-02-2019-0082

Nørreklit, H., Nørreklit, L. and Mitchell, F. (2010), Towards a paradigmatic foundation for accounting practice. Accounting, Auditing \& Accountability Journal, 23(6), 733-758. https://doi. org/10.1108/09513571011065844
Nørreklit, H., Raffnsøe-Møller, M., \& Mitchell, F. (2016), A pragmatic constructivist approach to accounting practice and research. Qualitative Research in Accounting \& Management, 13(3), 266-277. https://doi.org/10.1108/QRAM-05-2016-0039

Olivier, H. (2000). Challenges facing the accountancy profession. European Accounting Review, 9(4), 603-624. https://doi. org/10.1080/09638180020024052

Pham, D. H., Dao, T. H., \& Bui, T. D. (2020). The Impact of Contingency Factors on Management Accounting Practices in Vietnam. Journal of Asian Finance, Economics and Business, 7(8), 77-85. https://doi.org/10.13106/jafeb.2020.vol7.no8.077

Phornlaphatrachakorn, K., \& Peemanee, J. (2020). Integrated Performance Measurement as a Strategic Management Accounting Approach: A Case of Beverage Businesses in Thailand. Journal of Asian Finance, Economics and Business, 7(8), 247-257. https://doi.org/10.13106/jafeb.2020.vol7.no8.247

Phornlaphatrachakorn, K., \& Khajit, N. K. (2020). Strategic Management Accounting and Firm Performance: Evidence from Finance Businesses in Thailand. Journal of Asian Finance, Economics and Business, 7(8), 309-321. https://doi. org/10.13106/jafeb.2020.vol7.no8.309

Steurer, R., \& Konrad, A. (2009). Business-society relations in Central-Eastern and Western Europe: How those who lead in sustainability reporting bridge the gap in corporate (social) responsibility. Scandinavian Journal of Management, 25(1), 23-36. https://doi.org/10.1016/j.scaman.2008.11.001

Steurer, R., Langer, M. E., Konrad, A., \& Martinuzzi, A. (2005). Corporations, stakeholders and sustainable development I: a theoretical exploration of business-society relations. Journal of business ethics, 61(3), (pp.263-281). https://doi.org/10.1007/ s10551-005-7054-0

Stubbs, W., \& Higgins, C. (2014), Integrated reporting and internal mechanisms of change. Accounting, Auditing and Accountability Journal, 27(7), 1068-1089. https://doi. org/10.1108/AAAJ-03-2013-1279

Stubbs, W., \& Higgins, C. (2018). Stakeholders' Perspectives on the Role of Regulatory Reform in Integrated Reporting. Journal of Business Ethics, 147(3), 489-508. https://doi.org/10.1007/ s10551-015-2954-0

Terblanche, W., \& De Villiers, C. (2019). The influence of integrated reporting and internationalisation on intellectual capital disclosures. Journal of Intellectual Capital, 20(1), 4059. https://doi.org/10.1108/JIC-03-2018-0059

Tsai, F. M., Bui, T. D., Tseng, M. L., Wu, K. J., \& Chiu, A. S. (2020). A performance assessment approach for integrated solid waste management using a sustainable balanced scorecard approach. Journal of Cleaner Production, 251. https://doi.org/10.1016/j. jclepro.2019.119740 
